Предраг Ј. Мутавшић*

Универзитет у Београду

Филолошки факултет

Мерима Кријези

Универзитет у Београду

Филолошки факултет

Ана Б. Сивачки https://doi.org/10.18485/analiff.2018.30.1.14

811.163.41:811.135.1:811.18]'373.23

Оригинални научни рад

Примљен: 30.04.2018.

Прихваћен: 12.08.2018.

\title{
ФРАЗЕОЛОГИЗМИ СА ЛЕКСЕМОМ КОҢ У САВРЕМЕНОМ АЛБАНСКОМ, РУМУНСКОМ И СРПСКОМ ЈЕЗИКУ
}

\begin{abstract}
Рад, заснован на расположивом корпусу фразеологизама (посматраних и у ужем, правом фразеолошком, и у ширем, паремијском, спектру) ексцерпираном из релевантних речника, посвећен је анализи фразелогизама са кључном лексемом коњ у савременом албанском, румунском и српском језику. Како је коњ у многим културама, и код многих народа, перципиран као животиња од великог значаја, не само за свакодневни живот и преживљавање, већ и као животиња која се сматра изузетно чистом и плементиом, у раду је обрађена и семантичка анализа ове лексеме унутар фразеологизама. У раду такође настојимо да укажемо на то да ли има и у којој је мери могуће говорити о подударностима или неподударностима између анализираних фразеологизама у сва три савремена и несродна балканска језика.
\end{abstract}

Кључне речи: фразеологија, фрезеологизми, лексема кою, семантика, албански, румунски, српски, еквиваленција.

\section{1. Уводно разматрање}

Поред бика и краве, коњ се сматрао једном од најпоштованијих животиња у европским и светским културама ${ }^{1}$, будући да је у мито-

\footnotetext{
* Поштанска адреса: Филолошки факултет, Катедра за неохеленске студије, Студентски трг 3, 11000 Београд. Контакт (e-mail): predrag.mutavdzic@fil.bg.ac.rs.

** Рад је написан у оквиру пројекта Министарства науке, просвете и техничког напретка Републике Србије Језици и кулииуре у времену и йростиору (број 178002).

1 Посебна је занимљивост та да у грчкој преантичкој керамичкој уметности до данас нису пронађени материјални предмети у облику коња, или коњске главе, док
} 
лошким представама вукао кочије лунарних и соларних божанстава преко небеског свода. Ова симболика, која не указује толико на цикличност времена, колико пре на непрекидно кретање, може се протумачити реалним окружењем у којем су ти народи некада живели - реч је о њиховом полуномадском или номадском начину живота или о потреби мењања места, пресељавањима и насељавањима нових области услед ратова, најезда других народа и слично, при чему је коњ била једна од њихових главних превозних и товарних животиња. Посебно место коња у свакодневном животу људи додатно је било осигурано и тиме што су га, по правилу, имали углавном моћни, привилеговани и богати појединци у друштву, али и неустрашиви хероји и витезови опевани у народној јуначкој поезији или у легендарним причама. Код номадских народа коњ и појединац били су као једно: познато је из историје да је монголска инвазија на подручју Средње и Источне Азије у време Џингис-кана била веома успешна, између осталог, не само зато што су његови ратници били вични оружју, него и зато што су на коњима могли буквално и јести и спавати. Коњица je, све до пред крај 50-их година прошлога столећа, била ударна снага готово сваке европске војске, заједно са пешадијским формацијама.

И поред многобројних позитивних карактеристика које су коњима приписане у различитим културама, наилазимо и на негативне, попут оне да је коњ представник доњег света. Представници четири велика зла

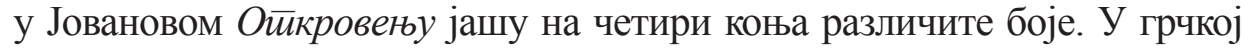
митологији, насупрот слободног белог Пегаза, који је ударцем копита створио свети извор Хипокрену (Іллокрү́үๆ, дословно: „коњско врело“) у Беотији, а кога су чувале свештенице са маскама коња, Пегае (Conway, 2005: 85), око кога су се окупљале Музе и из кога су песници, писци и музичари црпли своје надахнуће (Eason, 2008: 87; Christou - Papastamatis,

јеритон (рvтóv), употребљаван и зарелигијске и за свакодневне потребе, искључиво прављен у облику главе бика. Код Срба, Црногораца и Албанаца, на пример, на гуслама се врло често налазе симболи змије и орлова, а када је реч о накиту, одевним и другим употребним предметима у оквиру балканског ликовног репертоара углавном преовлађују симболички мотиви те (стилизовани) прикази митских бића (попут аждаје) или птица (и то искључиво орла и сокола). Ни у новије време фигура коња се није „показала“ пригодном у народној уметности, па отуда појава разноразних украсних фигура у облику кокошке, патке, гуске, затим окарине у облику рибе и слично. Са друге стране, у ликовним и примењеним уметностима врло често се прибегава фигури коња. 
ФРАЗЕОЛОГИЗМИ СА ЛЕКСЕМОМ КОґ У САВРЕМЕНОМ ...

2009: 26), стоји заробљен црни Арион (Арсí $\omega v)$ у подземљу као слуга у Хаду. У германској митологији mahrt (= „кобила“) било је биће које је оличавало злог духа из доњег света (Krappe, 1952: 229). И поред тога што се у европској гастрономској култури подразумева да се коњско месе не једе, понајпре из разлога што је коњ била света животиња и што се (чак и данас) сагледава као изузетно племенита, чиста и веома корисна, у оквиру римске и германске митологије коњ је ипак био ритуално жртвован: у првом случају богу Марсу, у знак захвалности за успешно обављену жетву, у другом ради стицања снаге и издржљивости. У индијским светим списима, Рївеgu, као и у спевовима Махабхарайи те Рамајани такође се приповеда о ритуалним жртвовањима коња

Божанска снага коњске природе се у митолошким представама објашњавала на различите начине. Тако се, код античких Грка, Посејдон сматрао творцем коња, а Зевс, његов брат, често се описује као божанство које се радо преображава у животиње, као што су лабуд, бик или коњ. Код Англосаксонаца је коњ била света животиња, оличење моћи и богатства. За многе митологије карактеристично је и то да се у њима јављају такозвана хибридна бића, полу-људи, полу-животиње, као што је у Индијаца Гаруда, орао са телом мушкарца, сфинга у Египћана, а Кентаур, човек-коњ у античких Грка. И код муслимана се сусреће једно такво хибридно биће, Бурак, коњ са крилима, пауновим репом, а лицем човека, који пророке преноси на небеса. Познато је и то да су Англосаксонци у својим паганским ритуалима славили божанство у облику полу-коња (O`Konel - Eri, 2007: 21).

Подручје Медитерана, тачније речено Егеја и Мале Азије, према ономе што су научници до сада успели да установе, изгледа да је одвајкада било важно када је реч о култури поштовања и узгајања коња. Назив средишњег дела Мале Азије, Кападокија, по појединим етимолозима, управо је потврда посебног односа човека према коњима: превод овог назива са староперсијског гласи „земља лепих коња“ (Schmitt, 1980: 399; Summerer, 2005: 135). Бројни дешифровани хетитски клинописи непосредно говоре у прилог хетитским вештинама и знањима о узгоју и начинима кроћења коња. Опсежна археолошка ископавања угледног немачког историчара и археолога Манфреда Корфмана (Manfred Korfmann, 1942-2005) у периоду 1990-2000. година на подручју Троје изнела су бројне доказе о томе да је овај древни град некада био важно европско и егејско-медитеранско стециште трговине (Korfmann, 1995: 181f; Korfmann, 1998: 380-383), између осталог и 
коњима. Огромне количине коњских костију, пронађених унутар зидина града, у археолошком слоју означеном као Троја VI (време датирања: 1700-1250. пре Христа), само су потврдиле оно што је Хомер у Илијаgи назначио: да су Тројанци одиста били „коњокроти“ (II, 3, стих 127). За Хетите је поуздано утврђено да су не само били вешти трговци и занатлије, већ и то да су били ти који су имали изузетно јаку коњицу те да су међу првима поседовали „борна кола“ која су вукли двојке, тројке а неретко и четворопрези. Како је показала једна краћа студија (Starke, 1995), Троја и шире подручје око ње били су заиста кључно средиште трговине коњима (Latacz, 2004: 102), ако не чак и велики центар њиховог узгоја. Отуда се, као чисто хипотетичко питање, може поставити и наредно: да ли је Тројански рат заправо вођен ради успостављања грчке превласти над овим изузетно важним центром коњарства, богатства и економске моћи, а да је прича о љубавном троуглу била само повод који је временом успешно замаскирао сву суштину. Посматрано из овог угла, сигурно је то да мотив о остављању (односно, о подметању) огромне фигуре дрвеног коња испред неосвојивих зидина Троје није без разлога наведен у Илијаgи те да има дубоког смисла: коњ, чак и као дрвен, био је од посебне вредности за Тројанце, будући да су они били везани за њега на нама данас прилично непознате начине 2 .

Једна Езопова басна приповеда како је човек укротио коња: коњ је имао целу ливаду за себе и мирно је на њој пасао када се изненада појави јелен те и он стаде да се гости травом. Коњ, смишљајући како да отера незваног госта, замоли човека да му помогне. Човек без већег размишљања пристаде, али под једним условом: да га опреми и зајаше. Тако се човек попе на њега, а коњ тада схвати да је тиме себе заробио довека служећи му³.

\section{2. Циљ, методологија рада, корпус}

Нема сумње у то да је човек у оквиру евро-азијских култура и цивилизација одувек био упућен на коња који је остао „bez jasnog privilegovanog statusa“ (Vidović Bolt, 2011: 57), мада богате фразеолош-

2 Не би требало искључити овде помисао да су Тројанци имали и неко своје божанство посвећено коњима, као што је то била келтска богиња Епона. О томе данас је мало познато.

3 http://gimnazija-sb.com/portal/wp-content/uploads/2015/02/ezop basne.pdf. Наведена басна се налази на 65 . страни. 
ке слике у савременим и несродним балканским језицима - албанском,

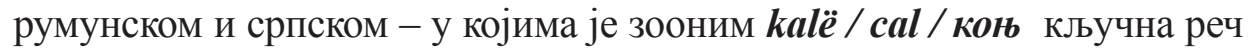
показују ипак нешто сасвим друго. Фразеолошку грађу смо ексцерпирали како из свих нама доступних штампаних и online једнојезичних и двојезичних речника на наведеним језицима (њихов потпуни списак налази се приложен на крају рада), тако и преко претраживача Google који нам је послужио само као секундарни облик потврде раширености употребе и значења свих забележених фразеологизама.

Главни циљ нашег рада састоји се у томе да покажемо како је искоришћена фигура коња у формирању фразеологизама. Ово, следствено, значи да је наша пажња усмерена и на формални морфосинтаксички и на семантички аспект, при чему настојимо да укажемо да ли постоје и у којој је мери могуће говорити о подударностима или неподударностима између анализираних фразеологизама. У раду смо се определили да све забележене конструкције називамо двојако, као фразеологизме (даље у тексту: ФРЗ) или као фразеолошке конструкције (надаље: ФК). У оквиру њих смо уврстили и паремије које, по свим својим унутрашњим (структурним) одликама, припадају посебној фразеолошкој групи, с обзиром да

„jе пословица имала основни услов да може да опстане као посебна - а он је потицао отуда што је садржала у себи лапидарно формулисану неку истину, у већој или мањој мери универзалну, често културолошки и на неки други начин ограничену, али свакако општу - она је настављала свој самостални живот и као говорна фраза и као усмена књижевна творевина“ (Бојовић, 2005: 54).

Полазећи од примера у примарним језицима нашег истраживања, албанском, румунском и српском, трагали смо за сличним ФК и у другим европским језицима како бисмо указали и на идиотипичност фразеологије сваког разматраног језика понаособ, али и на хомотипичност између њих, са једне стране, те на хомотипичност између њих и европских језика, са друге. Сви примери на албанском и румунском дати су као глосе (њихови дословни преводи дати су у заградама), а сви преводни еквиваленти на циљним језицима који припадају категорији нулте структурно-семантичке подударности обележени су звездицом. 


\section{3. О лексемама за именовање коња}

Лексикографски сагледано, поред главних (домаћих) речи којом се именује коњ, а које посматрамо као примарне, у албанском, румунском и српском језику, запажа се и неколико секундарних лексема страног порекла, као што су:

\begin{tabular}{|c|c|c|c|}
\hline језик: & албански & румунски & српски \\
\hline$\pi \alpha ́ \rho ı \pi \pi \varsigma_{>}>$ & 1 & parip & парип \\
\hline at (турски) > & at & (h)at & ат / хат \\
\hline bedevi (турски) > & atkinë & bidiviu & бедевија \\
\hline equus admissarius $>$ & hamshor / hajger & (h)armăsar & (пастув) \\
\hline
\end{tabular}

Поред наведених, у ову групу укључујемо и лексеме из домаћег вокабулара које имају везе са различитим именовањем коња, као што

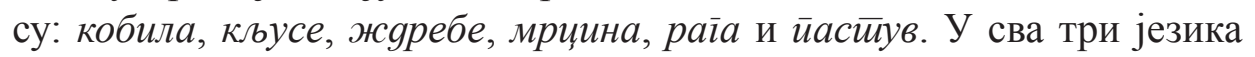
95\% забележених ФК искључиво је образовано уз помоћ примарне лексеме коњ, што ће рећи да смо у албанском забележили 43, у румунском 31, а у српском 29 фразеологизама. Преосталих 5\% примера чине ФРЗ с неком од наредних секундарних лексема:

\begin{tabular}{|c|c|c|c|c|c|c|}
\hline језик & секундарғ & лексема & & & & \\
\hline албански & pelë: 6 & mëz: 4 & / & / & gërdallë: 2 & / \\
\hline румунски & iapă: 2 & mânz: 1 & / & mârțoagă: 1 & gloabă: 1 & (h)armăsar: 1 \\
\hline српски & кобила: 1 & ждребе: 1 & кљусе: 1 & мрцина: 2 & рага: 2 & (пастув) \\
\hline укупно & 9 & 6 & 1 & 3 & 5 & 1 \\
\hline
\end{tabular}

Укупан број свих забележених ФК је 128, по језицима: албански 55 (42,96\%), румунски 37 (28,90\%), српски 36 (28,12\%). Из последњег табеларног прегледа се види да албанска секундарна лексема gërdallë покрива три одговарајућа засебна српска и два румунска семантичка појма: кљусе, мрцину и pā̄y, а синонимни румунски називи mârțagă и gloabă покривају сва три српска. Све ово указује да се у српском и у румунском праве посебна семантичка нијансирања у оквиру истог појма. 
ФРАЗЕОЛОГИЗМИ СА ЛЕКСЕМОМ КОњ У САВРЕМЕНОМ ...

\section{4. О фразеологизмима са лексемом коњ}

Посматрано са морфосинтаксичке тачке, код забележених албанских и румунских примера уочавају се извесне специфичности које се одражавају на правилно разумевање семантичке поруке ФК. Поред лексичких разлика (у смислу да се запажају могуће комутације појединих лексема), једна од специфичности албанског и румунског у морфолошком погледу, у односу на српски, огледа се и у томе што се у овим језицима номинали одликују флексијом у такозваном неодређеном и одређеном виду (trajta е pashquar / e shquar; nedeterminarea / determinarea) - сваком номиналу у оквиру његове падежне промене следи посебан флективан наставак за једнину и множину који морфолошки функционише или као неодређени или као одређени члан при чему се постиже јасно како семантичко и логично разграничење, тако и нијансирање појмова. Управо ова важна морфолошка разлика омогућава да се у оба језика успостави разлика између номиналне синтагме coadă de cal = bisht kali те синтагме coada calului = bishti i kalit. Док су у првом случају оба номинала дата у неодређеном виду, уз неминовне синтаксичке разлике, означавајући коњски рей, односно облик фризуре у виду коњског репа, у другом су случају исказани у одређеном виду, уз видљиву потпуну мофолошко-синтаксичку подударност, при чему означавају назив биљке у српском познату као иреслица (Equisetum sp.). У појединим језицима, као у енглеском и шпанском, на пример, назив ове биљке не разликује се ни морфолошки ни синтаксички од назива за фризуру - horsetail / cola de caballo.

Уколико посматрамо структурну и семантичку страну ФРЗ с лексемом кою у албанском, румунском и српском, примећујемо да њих деветнаест припада групи такозваних интернационалних, односно оних који се и у другим европским језицима препознају као такви. Од тог броја, свега седам из разматраних балканских језика апсолутно је подударно са ФК из других европских језика. па се зато може рећи да између њих постоји хомотипична повезаност, попут: тројански коњ = kali i Trojës = calul troian ${ }^{4}$; поклоњеном коњу у зубе се

4 У грчком постоји варијанта у којој се Троја не наводи, већ придев „дрвен“:

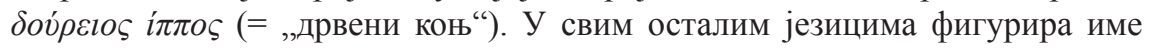
топонима, што се може посматрати као калк са латинског: Troianus equus. 


\section{не гледа = kalit të falur / të dhuruar nuk i shikohen dhëmbët = calul de dar nu se uita la dinți / în gură $(=, \text { у уста“ })^{5}$}

Приликом упоређења ове групе ФК уочили смо присустви варијаната у виду незнатних структурних, понајпре лексичких, померања, док се јасно препознаје очувана (иста) семантичка порука. Оваквих ФРЗ са делимичним стуктурним изменама је далеко више у односу на оне код којих се исказују потпуна структурна поклапања (укупно 12), што је сасвим разумљиво и у потпуном складу са народном филозофијом те светоназорима сваког народа понаособ у покушају приказивања (дочаравања) менталних слика:

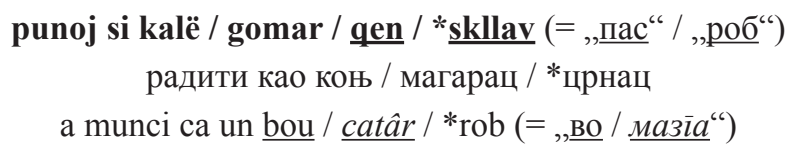

work like a horse / mule / dog $=$ wie ein Pherd schuften / $\operatorname{arbeiten}^{6}$

коњу, жени и пушци не треба веровати = pușca, calul și femeia / nevasta nu se împrumută / să nu te încrezi în femeie, în cal și în pușcă

kalit që djersitet dhe gruas qё qan mos $i$ zёr besë (= „коњу који се зноји и жени која плаче не узима се вера“") ${ }^{7}$

трпети као коњ / $\underline{\text { nac }}$

dhuroj si gomar (=,магарац“)

a suferi ca un câine

5 Ова паремија у латинском исказана је другим глаголом: equi donati dentes non inspiciuntur (= „не проверавају се“), али не у италијанском (a caval donato non si guarda in bocca), док у одговарајућој грчкој фигурира лексема магарац

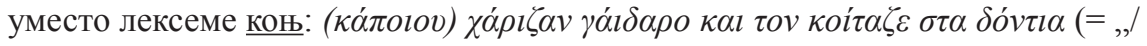
некоме/ су даривали магарца те му гледао у зубе“).

6 С овим глаголом цела фразеолошка конструкција у немачком носи значење: раяийи као ирв.

7 Упоредиво са: a horse, a wife, and a sword may be shewed, but not lent = dein Weib, dein Schwert und dein Pferd magst du wohl zeigen, aber nicht ausleihen (= „коњ, жена и мач могу се показати, не позајмити” / „твоју жену, твој мач и твога коња можеш још и показати, али не позајмити“") = tre cose lascia da per sè: l occhio, la donna e la fè (=,„три ствари остави за себе: око, жену и веру“). 
kali i mirë / i kuq e ka një huq (= „добар / црвени коњ има једну ману“)

и коњ оg сииоиину яукатиа йосрне

calul are patru picioare și tot se poticneste $^{9}(=$, „коњ има четири ноге и опет се споти-

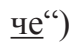

S'mëson kali revan në pleqëri (= „не учи коњ ра̀ван ${ }^{10}$ у старости“" $)^{11}$

calul bătrân cu gres se invată la ham / calul bătrân nu se mai învată în buiestru (=

„стари коњ се муком учи на ам“ / „стари коњ се никада не научи на ка̂с“)

матиор коњ се не учи иірайи / "gрво се савија док је млаgо

paște, murgule, iarbă verde! (= „паси, дорате, траву зелену!“")

не лийши маїарче gо зелене иираве / чекај, маїарче, gа иии Ђурђевgан gође!

prit, gomar, të mbijë bar! (= „чекај, магарче, да трава порасте!“) ${ }^{13}$

У односу на интернационалне, број истих ФК у албанском, румунском и српском изгледа овако:

а) између сва три језика уочено је тек 5 истих;

б) између румунског и српског постоји 12 истих;

в) између албанског и румунског забележено је свега 3 истих;

г) између српског и албанског постоји 9 истих.

8 Упредиво са колокацијом: нико није савршен / без мане. У руском би одговарајући еквивалент српском био: ни дерева без иоорока, ни коня без иооииычки.

9 Румунска паремија је интернационалног карактера, будући у потпуности адек-

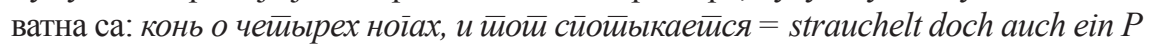
ferd und hat doch vier Beine $=i t$ is a good horse that never stumbles / a horse has four legs, but still stumbles = un cheval à quatre pieds et si chiet = e cade anche un cavallo che ha quattro gambe (= „чак и коњ пада који има четири ноге“). У латинском еквиваленту, на пример, уочава се и друкчији глагол и друкчија лексема: errat interdum quadrupes (= „греше каткада четвороношци“).

10 ра̀ван / ра̀хван (турцизам $)=$ ка̂с

11 У грчком ова паремија исказана је уз незнатну промену лексичког садржаја:

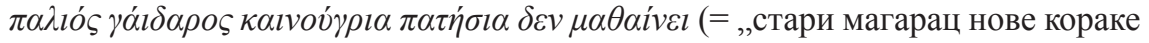
не учи“). У енглеском је такође лексички преобликована: you cannot teach an old dog new tricks, а у немачком се исказује на друкчији фразеолошки начин уз игру речима: was Hänschen nicht lertn, lernt Hans nimmermehr (= „што мали Ханс не научи, Ханс никада више не научи“).

12 У италијанском, на пример, одговарајући еквивалент наведеним конструкцијама јесте: campa cavallo che l'erba cresce (= „поживи, коњу, док трава израсте“).

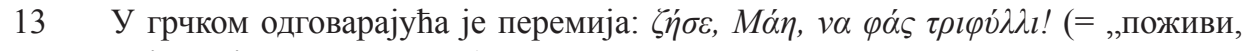
маје, да једеш детелину“). 
Појава истих ФРЗ у два балканска језика, много ређе у три, последица је како културног и интимног позајмљивања (Bloomfield, 1933: 444-460 и 461-475), тако и других спонтаних, врло снажних међујезичких утицаја на Балканском полуострву. У овом су погледу разматрани балканских језици идиотипични. Таква је, на пример, и наредна ФК са кобилом и ждребетом

i hipi kalit nga bishti / del si mëzi para pelës (= „попети се на коња са репа“ / „ићи као ждребе испред кобиле“")

ићи / скакайи као жяребе йреg pygv

a pune căpăstrul la coada calului / carul innaintea biolor / a umbla ca mânzul după

iapă (= „ставити узде на реп коњу / кола испред бикова“; „ићи као ждребе испред кобиле")

која се не препознаје ни у једном другом европском језику ${ }^{14}$, или паремија:

\author{
вежи коња где ти газда / ага каже ${ }^{15}$ \\ leagă calul unde zice stăpânul, măcar lupul să-l mănâce (= „вежи коња где ти каже \\ господар, макар га и вук појео“) \\ lidhe kalin ku të thotë "gazda"16 / zotëria / i zoti / padroni
}

\title{
или ФРЗ:
}

14 У енглеском и немачком ФК гласи: to put the cart before the horse / das Pferd von hinten aufzäumen, а на италијанском mettere il carro davanti a buoi, што је подударно са румунском другонаведеном синонимном као и са грчком у којој преовлађује незнатно друкчији тип обликовања потпуно исте фразеолошке

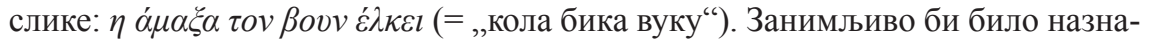
чити да се у савременом грчком данас све више може сусрести и синонимна

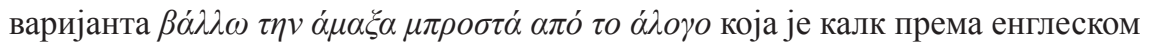
оригиналу (више о начинима преношења ове конструкције може се прочитати на наредној интернет страници: https://www.linguee.com/english-greek/ translation/cart+before+the+horse.html).

15 Исто и у немачком: binde das Pferd dort an, wo der Herr es befiehlt, а у појединим језицима уместо лексеме коњ лексема маїараи фигурира: lega l'asino dove vuole il padrone $=$ an ass must be tied where the master will have him.

16 Како се види из примера, и у језику Албанаца са Косова и Метохије појављује се модификован славизам који је ушао у српски, а потом у албански, у виду речи повратнице „газда“ (gazda). 
ФРАЗЕОЛОГИЗМИ СА ЛЕКСЕМОМ КОґ У САВРЕМЕНОМ ...

ka hipur mbi kalë / jam në majë të kalit (= „попео се на коња““ „бити на врху коња“) бити и на коюу a fi în $\underline{\operatorname{varf}}(=, \text {,врxy“" })^{17}$

У прилог потврде свему изнетом може још послужити и чињеница да се у језику Албанаца са Косова и Метохије може чути калк bie prej kalit nё gomar образован према већ наведеној српској $Ф K^{18}$, а која ce, као таква, не сусреће у језику Албанаца у Албанији. Још један вид фразеолошке подударности представља и истоветан израз у албанском и српском: имати коњске живце = kam nervat e kalit ${ }^{19}$ који одговара румунском делимично подударном а avea nervi de fier (= „имати живце од гвожђа“"). Са друге стране, ни румунски није одолео словенском притиску, па се у њему запажа конструкција a fi (slab ca) o mârțoagă (= „бити / слаб као/ мрцина“") која одговара српском битии / вући се као мричина.

Структурна померања која захватају лексичко поље унутар ФРЗ илуструју два албанска примера с лексемом коњ. Први гласи: (jam) kali drush (druve) (= дословно: „бити коњ дрва“) и употребљава се у ситуацином опису ,жртвеног јарца“, са том разликом што није реч о свесном жртвовању, сходно значењу фразеологизма према библијском тексту, него о томе да је некоме нешто задато, наметнуто, да се мора бавити решавањем проблема без свог свесног, односно вољног пристанка (укључења). Другим речима, овом конструкцијом се назначава да је особа исувише оптерећена, да јој је непотребно нагомилан (додат, задат...) посао, брига те да га није могла избећи, будући да то не зависи од ње. Друга конструкција: (jam) kali i belave (= дословно: „бити коњ белаја") у пренесеном значењу указује на оно што се у српском обично

17 У енглеском, на пример, и немачком постоје фразеолошке конструкције to be on top of (something) / an der Spitze stehen која су лажни пријатељ са српском бити / налазити се на врху, будући да означавају „изаћи на крај са (чиме) / изаћи (коме) на нос“, односно „бити на челу / предњачити“.

18 Било би од користи да прикажемо како се у другим језицима исти семантички смисао исказује: реч је о сликовито друкчијим и непоновљивим облицима фразеологизације: vom Regen in der Traufe kommen (= „од кише у капљицу доћи“), cseberböl vederbe (= „из кофе у ведро [сипати]“), tornare di papa vescovo / andare dalla padella nella brace (= ,вратити од папе бискуп““ /,ићи са тигања на угаљ”) =

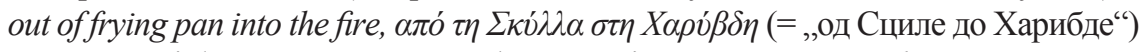

19 У одговарајућем грчком изразу фигурирају лексеме майарећи и сиирйљење:

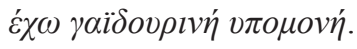


каже „бити дежурни коњ / магарац / мазга“. У овом погледу је реч о ономе који поступа као „Катица за све“, односно о човеку који решава све проблеме, али са том разликом да својевољно подмеће свуда своја леђа и ради све послове, а нико то од њега посебно не захтева ${ }^{20}$. У оба случаја указане $\Phi$ носе или јаку негативну конотацију или њу подразумевају, што зависи од непосредног ситуационог контекста. Колико нам је познато, једино се албански језик одликује оваквим квалификативним конструкцијама у односу на друга два разматрана језика (па и у оквиру целокупног балканског фразеолошког корпуса).

Једна од специфичности балканске фразеолошке слике у оквиру разматраних језика јесте и напоредна употреба зоонима кою и маїарац унутар исте ФК (са или без синдета), у виду оштре антонимијске семантичко-функционалне опозиције, при чему се ове животиње упоређују или се доводе у везу на најразличитије метафоричне начине. Како се види из примера: највећи проценат ФК се у циљним језицима исказује преко нултог облика еквиваленције, што указује да је у овом погледу сваки балкански језик идиотипичан на свој начин:

kali ha tagjinë, gomari mbart bucelat (= „коњ једе крмиво, магарац бачве носи“)

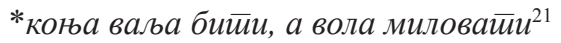

*unul taie și croiește, și altul stă și potrivește (= ,jедан сече и кроји, а други удешава и стоји“)

a nu fi nici cal, nici măgar ${ }^{22}$ (= „не бити ни коњ, ни магарац“)

*(nuk është) as mish, as peshk (= „/није/ ни месо, ни риба“)

*нитии смряи, нитии мирише

20 Уколико се инсистира на томе да се укаже како је неко заиста спретан, вешт, умешан у свему, да му све иде од руке, у албанском he се рећи jam i zoti / i pashoq / e pashoqe (= „бити способан / беспрекоран / ненадмашан/“), у смислу „немати премца“, „бити изузетан“ (синонимно у српском са: „бити од прве руке“).

21 Смисао је: „док један ужива, други се уби од посла“.

22 У разматраним језицима постоје синонимне варијанте које укључују елемент људског оглашававања, па у том погледу показују далеко виши степен семантичке и структурне хомотипичности: ниии збори, нитии ромори, а пи zice nici cârc nici mârc (= „не рећи нити крк нити мрк“), nuk bën as gëk, as mëk (= „не чини ни гук, ни мук“) 
kur ishe mbi gomar e doje dhe hënën, sot ke hip mbi kalë dhe s'e do as nënën (= „када си био на магарцу и месец си волео, данас си се попео на коња и чак ни мајку не волиш“) $)^{23}$

* нема їореї, неі̄о каgа се иииква йокондири

*a fi cu fumuri in cap (= „бити са димовима у глави“)

уочава се и фразеолошка идиотипичност - због апсолутне нулте структурно-семантичке еквиваленције - и фразеолошка хомотипичност код које се запажају потпуно исти ФРЗ као преводни еквиваленти у два језика, без обзира на то да ли они структурно-семантички одговарају или не ФК у језику са којим се упоређују, или је реч о подударању између преводног еквивалента ФК једног језика и њој одговарајуће у полазном језику:

punon kali, ha gomari (= „коњ ради, магарац једе“)

boii ară și caii mănancă $\left(=\right.$,волови ору, а коњи јеgy“") = волови ору, а коњи зобљу ${ }^{24}$

kali humbi, gomari s'duket (= „изгуби се коњ, магарац се не појављује“)

*јеgан у клин, gруїи у йлочу = *unul una, altul alta (= ,jедан једно, други друго“ $)^{25}$

shkova në kalë, erdha në gomar (= „отидох на коњу, вратих се на магарцу“) изјела коња иирава

*a fi mai scump ața decât fața (= „скупља је нит, него предњица“)

\section{коња с магарцем не вреди упоредити ${ }^{26}$}

gomarit kalë s'i thonë asnjëherë (= „магарцу да је коњ никада не кажу) ${ }^{27}$

*a aduna merele cu perele ${ }^{28}$ (= „додати јабуке са крушкама“)

23 Смисао је да се укаже да „када си био нико и ништа, био си човек, сада када имаш све више то ниси“".

24 Упоредиво са српском паремијом: ко йлаћа, њеі̄ова се свира, која је веома

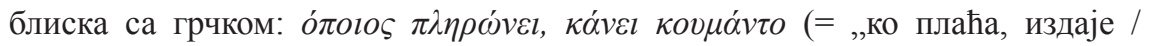
дословно: чини/ наредбу“. Синоним: яок је буgала, йамейни ће уживайи.

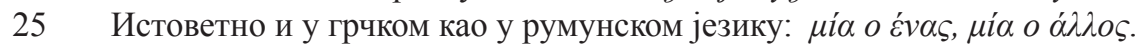

26 Упоредиво са далеко познатијом конструкцијом: не можеш мешайи бабе и жабе.

27 Синонимно са: *përzihet si bolla me ngjalën (=,„меша се као смук са јегуљом“).

28 Синонимно са: *a fi ca vaca și izmenele (= „бити као крава и дуге гаће“). 


\begin{abstract}
decât un cal obosit, mai bine un măgar odihnit (= „од уморна коња, бољи је магарац одморан“" $)^{29}$

më mirë gomar, po tëndin, se kalë, po të botës (= боље магарац, али твој, него коњ, но света [тј. свачији]“)

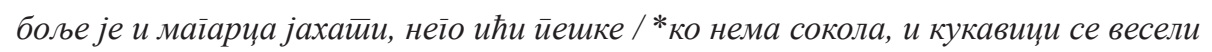

a schimba calul pe măgar / capra pe gâscă (= „заменити коња магарцем / козу гуском“") = ndërroj kalin me gomar

*ићи / йоћи оg зла на їоре

пасти са коња на магарца

a face / ajunge din cal măgar / cade de pe cal, se urcă de pe măgar (= „учинити од коња магаре / стићи са коња [на] магаре“; ,пада са коња, пење се на магарца“) = bie nga kali (= „пасти са коња“) / la kalin e mori gomarin (= „оставио је коња, а узео магарца“) / zbriti ( u ul) nga kali / shala e hipi në samar (= „сишао је са коња / седла, а попео се на самар“") 30
\end{abstract}

У свим примерима фигура коња поседује изразиту симболику, посебно уколико знамо да је коњ оличавао у некада прилично сиромашним балканским срединама једну од великих материјалних вредности којима је располагао појединац те да га је поседовање коња уздизало у друштвеном и економском погледу. Зато се коњ није могао мерити са магарцем као далеко јефтинијом и заступљенијом вучно-товарном и превозном животињом у свакодневном животу, посебно у брдским и планинским крајевима. Свако ко је имао коња у штали сматрао се привилегованим чиме је потврђивао свој издвојен (донекле и повлашћен) друштвени статус.

Комутација лексема кою и маїарац унутар исте ФК, забележена у свега неколико примера, битније не утиче на промену значења, а свакако доприноси појачавању стилског ефекта те наглашавању поруке чиме се подиже интензитет исказу:

nuk i shkoi kali / gomari në udhë / urë (= „није отишао магарац / коњ на пут / мост“)

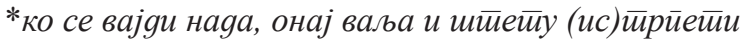

*nu i-a mers / ieșit așa cum credea (= „није му пошло / изашло како се надао“)

29 И у мађарском постоји слична ФК: ha ló nincs, a szamar is jó (= „ако нема коња, и магарац је добар“).

30 Упоредиво са синонимном ФК: prish stëpi e bën kasolle (= „срушити кућу и направити колибу“'). 
ФРАЗЕОЛОГИЗМИ СА ЛЕКСЕМОМ КОґ У САВРЕМЕНОМ ...

\author{
punoj si kalë / gomar / *skllav (= „poб“) \\ радити као коњ / магарац ${ }^{31} /$ * црнац \\ a munci ca un bou $/$ catâr $/ *$ rob $(=$, ,BO $/$ Masīa“ $)$
}

\title{
4.1. Фразеологизми изведени од примарне зоонимске лексеме
}

Из до сада показаног, али и из примера који следе, може се увидети да превагу односи нулти апсолутни степен стуктурно-семантичке подударности између разматраних балканских језика $(87,92 \%$ од свих забележених примера), без обзира на то да ли су ФК у језику од кога се креће изведене од примарне или од неке секундарне зоонимске лексеме. У оквир неподударности улазе и сви они случајеви када у преводним еквивалентима одусуствује примарна зоонимска лексема или је она замењена неком секундарном:

vajte ku shkon këmba e kalit (= „отиде где иде нога коња“)

a trimite pe (cineva) unde a dus (surdul roata și) mutu'iapa (= „послати /некога/ где је одвео /глув точак а/ нем кобилу“")

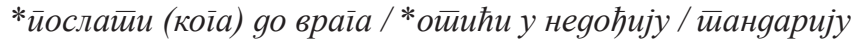

ra / zbriti nga kali (= „пао је са коња“)

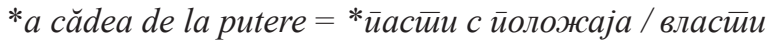

i ka hipur kalit qorr (= „попео се на ћоравог коња“)

* а fi о саиză pierdută = *биии изіуубљен случај / као іууска у майли

a dezlega calul de la gard = zgjidh kalin nga gardhi (= „развезати коња с ограде“)

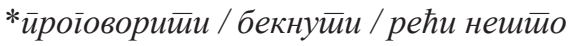

коња можеш дотерати до воде, али га не можеш натерати ни да пије д2 $^{32}$

pe porc nu-l faci să bea apă din fedeles (=, „свиња се не може натерати да пије воду из валова“)

31 Упоредиво с италијанским фразеологизмом: lavorare come un asino.

32 Упоредиво са: you can lead a horse to water, but you cannot make it drink=

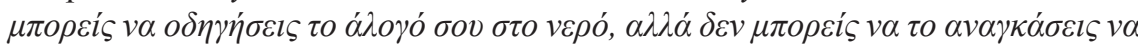
$\pi \imath \varepsilon i=$ man kann die Pferde zur Tränke führen, saufen müssen sie selbst. $\mathrm{y}$ италијанском се запажа друкчији вид фразеологизације истог семантичког смисла: non si può far bere l'asino per forza (= „не може се натерати на силу магарац да пије“) који је умногоме близак указаној румунској конструкцији. 
Предраг Ј. Мутавџић, Мерима Кријези, Ана Б. Сивачки

господареве очи коња гоје = sytë e zotit e tagjitin kalin

лакше (je) коњу без самара са $^{33}$

*s ’e ka vrarë samari (= „није га убио самар“)

u rrëzua kali, t’ i presin këmbët (= „паде коњ, да му секу ноге“)

*неће ваљgа йаgайи йлаве (збої /чеїа/) = *nи е de a-i zbura capul (cuiva) de (cineva / ceva) (= „није да лети /коме/ глава због /кога - чега/“)

Занимљива је и наредна паремијска конструкција у српском у којој се доводе у непосредан ирационални додир две врсте животиња између којих, према свим њиховим карактеристикама, не постоје никакве блиске и/или додирне везе:

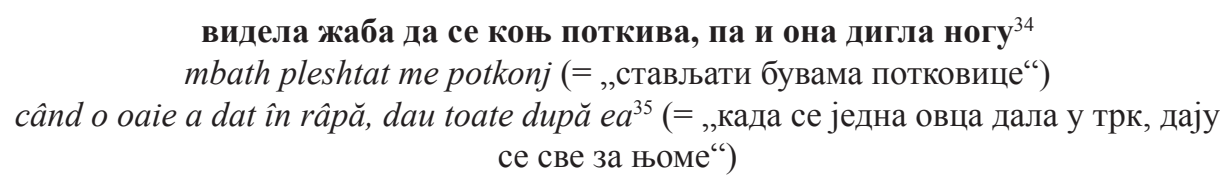

Приказивање оваквог односа, који се своди на пуко понављање поткивања, има главни задатак да укаже на сву парадоксалност описаног дешавања и на крајњу немогућност његовог остварења. Ма колико нам се чинила да је указана фразеолошка конструкција изворна српска, она се проналази у готово неизмењеном облику у грчком:

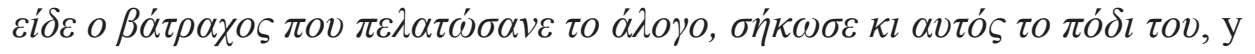
турском: ata öküze nal çakıldığını görmüs, kurbağa da ayă̆ını kaldırmış (= „видела их жаба како поткивају, и она дигла ногу такође“), те у

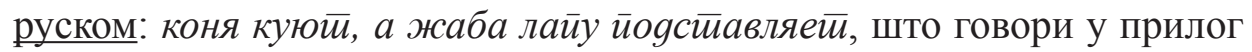
о релативној макрораширености ове пословице. Како је карактеристична за источни део европског континента, изгледа да је она ту и

33 У италијанском: senza basto siamo liberi (= „без батине смо слободни“).

34 У италијанском је занимљив поступак фразеологизације у коме је искоришћен мотив способности жабе да може „растегнути“ своју кожу: la rana gonfiò la sula pelle rugosa per essere più grossa del bove e scoppiò (= „жаба наду своју кожу да буде већа од бика те пуче“).

35 Упоредиво с енглеским: if one sheep leaps over the dyke, all the rest will follow. У грчком такође постоји одговарајућа паремијска конструкција са зоонимом, уз

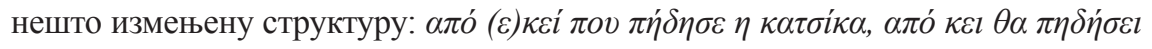

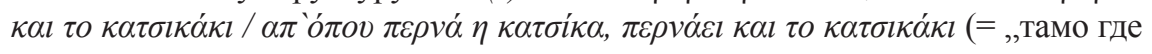
је прескочила коза, прескочиће и козлић““ „где прође коза, пролази и козлић“). 
настала. Који би језик могао бити изворни, нерешено је још питање, мада се, по свему судећи, може узети да је то био или турски, или неки туркијски језик (при чему је у том случају турски био само језик поседник). Идеја за овакво размишљање потекла је због велике сличности ових израза у турском и грчком, односно појаве калка у грчком.

Из расположиве грађе наишли смо и на наредну ФК у албанском shkoj me kalin e Nastradinit (= „ићи Настрадиновим коњем“) непознату осталом балканском подручју, а која, сходно нашим сазнањима, поседује своје одговарајуће преводне еквиваленте још једино у енглеском и у италијанском: andare col cavallo di san Francesco (= „ићи коњем светог Фрање“) = to go on / by Shankey's pony (= „ићи Шенкијевим понијем“"). Релативно велику блискост с италијанским исказује румунски фразеолошки еквивалент a merge apostolește / pe jos / per pedes (= „ићи апостолски / пешице“), у смислу да је у њега уткан хришћански елемент $^{36}$, док се сви наведени фразеологизми на српски једино могу пре-

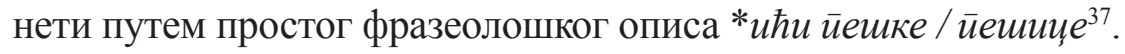

\section{2. Фразеологизми изведени од неке секундарне зоонимске лексеме}

Како смо претходно назначили, иако у сваком језику постоји развијен лексички секундарни фонд, тек је само одабрани број ових лексема послужио за грађење ФК у сва ти језика, попут:

a face din cal măgar și din țânțar armăsar (=, правити од коња магарца и од муве пастува“")

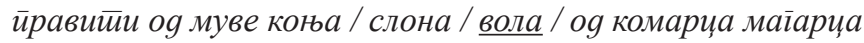
e bën mizën / pleshtin buall / $\underline{k a}$ (= „правити муву / буву биком /

36 Баш као што су апостоли, ширећи Христово учење, ишли пешке и одбијали да се превозе коњем (или неким другим превозним средством), чиме су исказивали своју скромност и покорност, тако је поступао и свети Фрањо Асишки, заступник учења о светом сиромаштву и аскетизму у животу.

37 У немачком, на пример, сасвим је други начин фразеолошког исказивања истог смисла: aus Schusters Rappen reisen (= "путовати на шустеровом рапу"). Rappen је стоти део швајцарског франка, пара. 
Предраг J. Мутавџић, Мерима Кријези, Ана Б. Сивачки

a fi gloabă $\breve{3}^{38}$ (= „бити рага“")

битии ислужена раїа

* i ranë potkonjtë (= “отпадоше му потковице“)

a bate şaua să priceapă iapa (= „ударати седло да разуме кобила“)

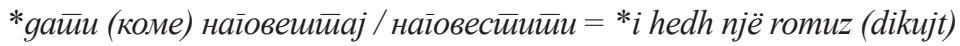

(dikë) e zunë me pelë për dore / në dorë (= „ухватити /кога/ са кобилом у руци“)

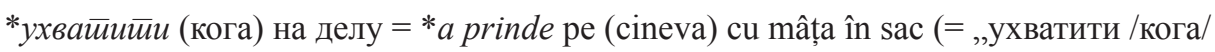
са мачком у врећи“)

e paguaj (diçka) një thelë sa për një pelë ${ }^{39}$ (= ,платити /шта/ једну кришку као једну кобилу“)

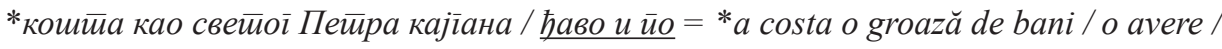
un drac si jumătate (= „,кошта грозоту пара“ / „, [читаво] имање“ / „ђаво и по“)

çoj një pelë e ha një thelë / çoj një thelë sa për një pelë (= “одвести кобилу, а појести кришку“ / „одвести кришку као за кобилу“)

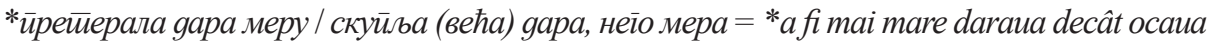

të jep një thele e të merr / rrëmben një pelë (=, да ти да̂ једну кришку, а да ти узме кобилу“)

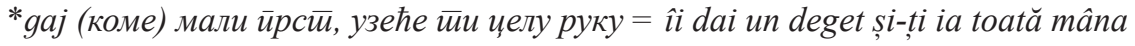
është një pelë në dorë (=,„то је кобила у руцу“)

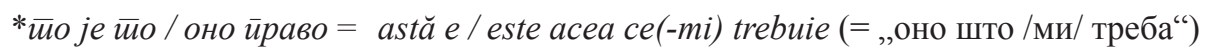

уздати се у се и у своје кљусе

kali i botës / $i$ huaj të lë në mes të udhës ${ }^{40}$ (= „туђег коња остави на сред пута“) *ce-și face omul cu mâna lui e bun făcut (= „оно што човек својом руком уради, то је добро урађено“)

(është) një vrap pele $=$ (este) o fugă / alergătură de cal $(=$,/то је/ један скок кобиле / коња“) (налазити се se / бити) у gва скока

38 У оквиру овог колоквијалног израза подразумева се да је реч о „ислуженој проститутки“, што то није случај у српском.

39 Упоредиво са: paguaj si frëngu pulën (= „платити као Француз кокошку“).

40 Упоредиво у потпуности са наредном паремијом: kush pret të hajë në çanak të tjetërkujt, mbetet shpesh pa ngrënё giё (= “ко чека да једе из туђег чанка, често остане празног стомака“). Превод на српском смо стилизовали ради постизања риме. 
чија је кобила онај највише за реп вуче / *Бог је себи прво браду створио *ai qё rri nën dardhë, $i$ ha kokrrat (= „онај што седи под крушком, једе плодове“) *nu da cămasa pentru altii, ca tu să rămâi în pielea goală (= „не подај кошуљу другима, јер остајеш [као] гола кожа“)

shtëpia / makinë gërdallë (= „кућа / аутомобил рага“)

*руина ( стираћара) / шклойоичја = *ruină / mașina rablă

\section{5. Симболика потковице}

Како се уз коња, по правилу, везује и потковица, ова лексема учествује у грађењу једног низа ФК у разматраним језицима (неке од њих су већ наведене):

caută (umblă după) potcoave de cai morți / caută (umblă după) cai morți, să le ia potcoavele (= „тражити потковице /ићи за потковицама/ мртвих коња“ / „тражити мртве коње /ићи по мртве коње/ да им се узму потковице“") presin të ngordhë gomari qё t'i marrin potkonjtë (= ,,чекају да цркне магарац да му узму потковице“)

йоикиватии / шибайи лийсала коња

a-și lăsa potcoavele / oasele undeva

оставити своје кости негде

i la kockat udhëve / rrugëve (= „оставио је кости улицама / друмовима“)

a-și lepăda potcoavele (= „испустити [од себе] потковице“)

$i$ ktheu potkonjtë (këmbët / këpucët) nga dielli = ia tregoi potkonjtë / këpucët diellit

(qiellit) (= "окенуо је потковице /ноге / ципеле/ од сунца“ / „показао је потковице / ципеле сунцу / небу“")

* ойеїнуиии ииайке / ирћи

kur t’i hipësh kalit, shihi potkonjtë (= „пре него се попнеш на коња, погледај му потковице")

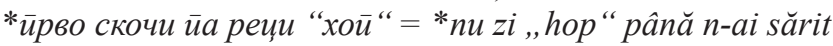

për një gozhdë shkoi potkoi (= „због једног клина оде потковица“)

због клинца изгубио коња / *клатии вола збої киле меса 
Предраг J. Мутавџић, Мерима Кријези, Ана Б. Сивачки

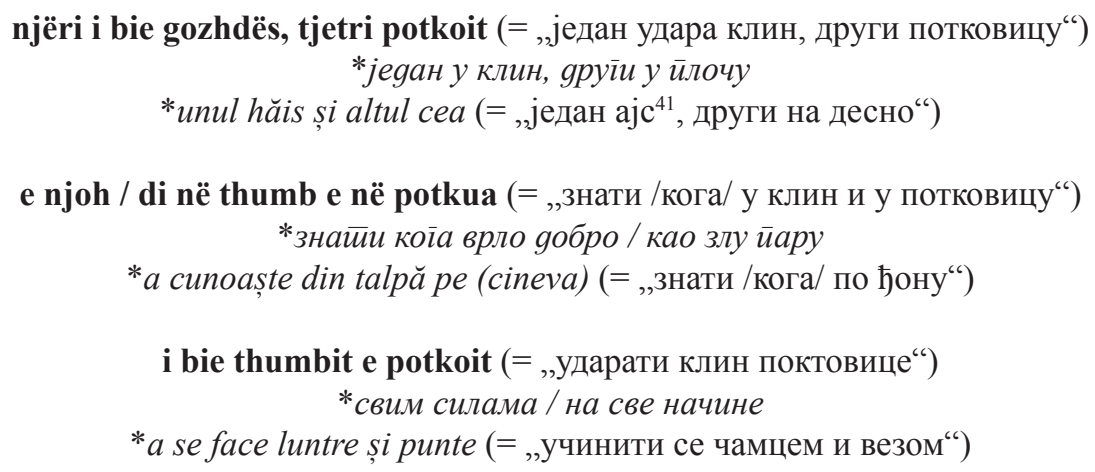

Потковица се одувек сагледавала као посебан знак среће, поготово уколико се нађе на путу, те отуда распрострањено веровање да ће налазача обасути великом радошћу и благостањем. Како смо већ назначили, коњ је важио за свету животињу и био је жртвован. Иако нема поузданих података који би могли додатно поткрепити због чега су потковици приписана магична својства доношења добрих знамења, баш као што нема ни када је реч о зечијој шапи, могуће је претпоставити да је управо ритуално жртвовање коња било главно за настанак овог веровања: како их је коњ (холоним) носио, сматрало се да су се на потковице (мероним) пренела сва његова позитивна својства која ће се даље пренети на онога који их поседује. Отуда је истицање потковице на видљивом месту, обично на улазним вратима куће, требало да послужи као амајлија за терање злих духова, демона, ђавола и других нечастивих створења.

Без обзира на сва магично-позитивна својства приписана потковици, оно што се нуди у оквиру фразеолошке слике разматраних балканских језика, по нама, указује на нешто сасвим друго. Тако се у првонаведеном румунском и албанском ФРЗ уочава једна крајње практична слика - није ту реч ни о каквом савременом еколошком питању и рециклажи, него пре о материјалној вредности потковице: како је било веома тешко доћи до метала, било је права штета да се добре потковице не искористе, односно да се не скину с угинулог коња. Нешто слично може се уочити и у српској паремији која поседује праву саветодавну функцију: мртви се коњи не кују, него раскивају. Да је потковица симбол и извесног знања, мудрости, види се у српском

41 Реч је о узвику којим се гони коњ да крене. 
у оквиру аналитичког ФРЗ бити (добро) поткован у (чему) који има одговарајући еквивалент у руском быт̄̄ (хорошо) йоgкованнылм в

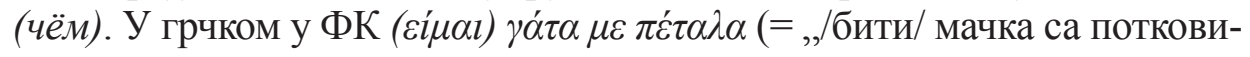
цама“") потковица носи сасвим супротно значење: не адекватног знања, већ претеране умишљености, односно убеђења да неко много зна и да је паметан (српски преводни еквиваленти би зато били: „правити се паметњаковићем / „изигравати паметњаковића“), што се знатно разликује од претходно наведене српске паремије са жабом и поткивањем којом се указује како неко без размишљања подражава оно што други чини. У румунском, са друге стране, глагол a potcovi, осим што значи ,потковати / поткивати“, у колоквијалном дискурсу носи ознаку и „преварити“, „насамарити“, а може означити и „научити памети кога“ у изразу te(v)oi potcoi eu pe tine (=,„потковаћу ја тебе“) кога углавном родитељи упућују деци као претњу или опомену.

\section{6. Семантичка поља фразеологизама са саставницом кою}

Са семантичке стране, сви забележени ФРЗ са саставницом кою указују на низ различитих когнитивних поља која су и позитивна и негативна - првих је далеко мање у односу на друге - а укупно је реч о 33 засебна концептуална поља. У највећем броју случајева обично по два ФРЗ, од којих сваки припада засебном језику, исказују исти семантички (конотативни) концепт, много је ређе да је реч о три иста, а није редак случај да се исти концепт у једном језику изражава и преко две или три синонимне ФК. Исто тако, поједини концепти се изражавају само путем једног ФРЗ у једном језику.

Семантички значај коња за свакодневни живот код Албанаца, Румуна и Срба, у смислу да је коњ био не само главна товарна (радна) животиња, него је представљао и својеврсни однос вРедности у виду каквог посебног квалитативног својства или какве добре умешности и способности. Ово схватање показују следећи ФРЗ:

calul bun se vede din grajd / se laudă singur / se vede de la ieslă (=,„добар коњ се види у штали / хвали се са̂м / се види по јаслама“")

за добрим коњем и прашина се диже / за добрим се коњем бат чује

*lajmet e mira përhapen larg, por të këqiat edhe

më larg (= добар глас далеко иде / допире / се чује, а зао још даље) 
kali i mirë e shton vetë tagjinë (= "добар коњ са̂м себи сипа крмиво“)

*prin muncă şi prin stăruință vei ajunge la dorință (= „пре посла и пре тежње стигни до жеље")

*ко умије, ьему gвије

kali i mirë njihet nën mutaf (= „добар коњ се познаје под покривачем“) = добар

коњ

се ц् под лошим покривачем познаје = calul bun se cunoaște și

sub un țol vechí ${ }^{42}(=$, ,стар“)

Релативно блиском овом јесте семантичко поље ВЕРЕ у САМОГ СЕБЕ и сопствене способности и моћи (знање, властиту снагу), обично услед или (искуственог, стеченог) недостатка поверења и жеље да други притекне у помоћ или услед нерачунања на туђу помоћ исказују српски и албански ФРЗ:

уздати се у се и у своје кљусе

kali i botës / i huaj tëlë në mes të udhës

*ce-și face omul cu mâna lui e bun făcut

У сва три језика постоје јасно дефинисана наредна семантичка поља:

ПонижЕњА: саговорник се намерно своди на пуки ниво животиње, односно семантички се са њоме изједначава, истовремено унижавајући га и одузимајући му сва људска својства. :

$$
\begin{aligned}
& \text { pelë = iapă! = кобило (једна)! } \\
& \text { коњу један! } \\
& \text { gomar! = măgarule! (= „магарче!) }
\end{aligned}
$$

ВРЕМЕНА, односно посебног временског тренутка, које се изражава на два начина:

а) или као концепт на чију реализацију треба релативно дуго чекати:

42 Подвучени су делови паремија који су проширени у односу на албанску полазну. 


\section{paște, murgule, iarbă verde!}

не лийии маїарче gо зелене йраве / чекај, маїарче, gа иии Ђурђевgан gође! prit, gomar, të mbijë bar!

б) или као концепт који се никада неће остварити, догодити у будућности:

la Paștele cailor (= „на Ускрс коња“)

*kur të hipë gomari nё fik (= „када се магаре попне на смокву“)

*cве ће бити gо у ћосе браgа

ГУБИТАК СТАТУСА, одНосНо Каквог стеченог друштвеног Положаја, па и економске моћи, изражава наредни заједнички ФРЗ:

\section{пасти са коња на магарца}

a face / ajunge din cal măgar / cade de pe cal, se urcă de pe măgar bie nga kali / la kalin e mori gomarin

Негативне концепте носе следеће ФК које исказују иРонију, преко сарказма и подсмеха:

vrei / mănânci, calule, orz / ovăz? (= „да ли желиш / да ли једеш, коњу, јечам / овас?")

* а gа нећеш можgа и...

*do dhe Muçoja kafe (= „и Мучо хоће кафу“)

a fi cal de bătaie (=,бити коњ од битке“)

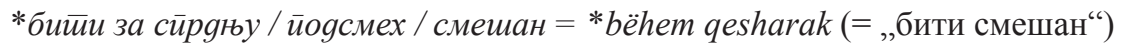

\section{a bate calul care trage $=$ удри коња који вуче}

те лЕњост и нерад:

rri si pelë (= „седети као кобила“)

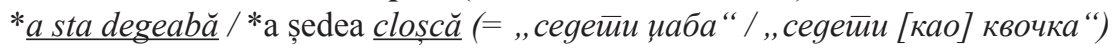

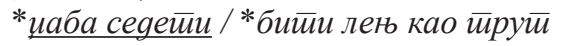

jam si kali në lëmë (= „бити као коњ на гумну“)

* a mânca pâinea degeabă = *иабе хлеба јест̄u 
Посебна особитост албанске и српске фразеолошке слике у односу на румунску (па и на осталу балканску) огледа се унутар свега неколико забележених фразеолошких конструкција у којима је лексема kale / коњ добила проширено семантичко значење - она фигурира као посебна јединица количине, те би у том погледу била семантички подударна с албанском лексемом „товар“ - као што се види у оквиру наредних израза:

a) kam një kalë punë / plaçka (= „имати једног коња посла / ствари“)

б) bëj një kalë fjalë (= „учинити једног коња речи“)

в) rri me një kalë tureçka (= „седети са коњем њушки“)

г) дати (коме) коњску дозу ${ }^{43}$

Њихови преводни еквиваленти на циљним језицима показују стуктурна или делимична поклапања или непоклапања:

а) иматии бряо (іомилу) иоосла / сиивари a avea o grămadă de treabă / mult de lucru (= „громаду“)

б) изїоворитии бряо / іомилу речи = a spune o grămadă de cuvinte / multe $e^{44}$

в) *a lăsa / pune nasul în jos (= „пустити / ставити нос на доле“) = *оклембесийи нос

г) *i jep dikujt një dozë shumë të madhe (= „дати /некоме/ велику дозу“)

Како се може сагледати из једне шире слике, ово је типичан случај уланчавања: постоји јасна слика коња који вуче товар, а коњ се затим метонимијски доживљава као тај товар који вуче (дакле, реч је о замени на релацији део - целина), па отуда појава коња унутар семантичког поља МЕРА, односно сразмере, као посебно одређене „мерне јединице“. С друге стране, као што су стопа, лакат, педаљ и сличне лексеме метонимијски постале мерне јединице, тако је овде то случај с коњем. У суштини, није ништа друго до најобичнија метонимија у комбинацији са искуственом сликом. У изнетим примерима се запажа хипербола којом се указује на велику (неодређену) количину нечега, односно на меру која је понекад несразмерна, неједнака:

43 Упоредиво с италијанским и руским конструкцијама: dare( a qualcuno) una dose da cavallo / лошаgиная gоза.

44 И у албанском се може исто тако рећи: kam një mal me рипё (=,,имам једну планину са послом“). 
ФРАЗЕОЛОГИЗМИ СА ЛЕКСЕМОМ КОґ У САВРЕМЕНОМ ...

çoj një pelë e ha një thelë / çoj një thelë sa për një pelë

*претерала / ирревршила gара меру = *a fi mare daraua decât ocaua

për një gozhdë shkoi potkoi

збої клиниа изйбитии коња / *клайи вола збоі киле меса

shkova në kalë, erdha në gomar

изјела коњ а иррава

*a fi mai scump ața decât fața (= „скупља је нит, него предњица“)

или прецењена:

e paguaj (diçka) një thelë sa për një pelë

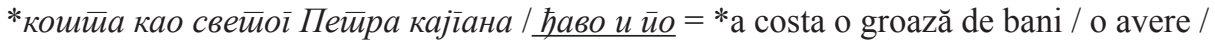
un drac și jumătate

Слично као и у претходним примерима, смисао наредног румунског ФРЗ јесте да прикаже досезање крајње мере, границе (на пример, нечијег стрпљења, снаге, издржљивости): a sări peste / de pe cal (= „скочити преко / до коња“) = *иревршитии сваку меру

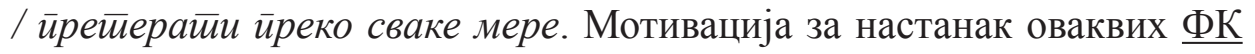
лежи у реалном животу и у човековом непосредном окружењу, с обзиром да је коњ једна од највиших познатих домаћих животиња те да га није лако досећи, прескочити.

Изражавање сематичке негативне квалификације постиже се путем дескрипције нечијег тренутног, уобичајеног или непримерног понашања:

\author{
jam si kali në ahur (= „као коњ у штали“)

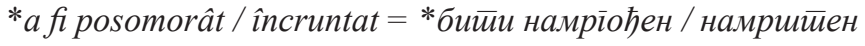 \\ jam si kalë azat / pa fre = a fi fără frâu \\ бити разуларен / разуздан \\ i ka hipur kalit qorr \\ * а fi о саиză pierdută = *бийи изіуубљен случај / као іууска у майли \\ a-și juca / alerga calul (= „играти се коња / истрчавати се [као] коњ“) \\ *изводийи бесне іллисте
}

a fi cal de dârvala (= „бити коњ за мучан рад“)

*бити сиров(ина) / іруб / неоиесесан 
Следећа семантичка поља припадају концептуалном домену исказивања:

- НЕЗАИНТЕРЕСОВАНОСТИ, оДНОСНО ПОТПУНОГ ЛИЧНОГ ИСКљУчења:

s`i kam hipur atij kali (= „нисам се попео на тог коња“)

*a nu fi de nici o treabă (= „не бити ни од каквог посла“)

*не битии из ие ириче

kur të më ngordhë mua kali, mos priftë fijë bari (= „,када ми цркне коњ, нека не изникне ни влат траве!")

*йосле мене, (нека буgе и) йойой = *dирӑ mine, potopul!

-НЕЈЕДНАКОСТИ, неравноправности У друштву:

kali ha tagjinë, gomari mbart bucelat (= „коњ једе крмиво, магарац вуче бачве“) коња ваља битии, а вола миловаии

*unul taie și croiesțe, și altul stă și potrivesțe

- МЕЂУСОБНОГ НЕРАЗУМЕВАњА:

njëri i bie gozhdës, tjetri potkoit (= ,jедан закуцава клин, други потковицу“)

јеgан / ко у клин, яруїи / ко у иилочу

*unul hăis și altul cea

kali humbi, gomari s'duket

*јеgан у клин, друїи у йлочу

*unul una, altul alta (= "један једно, други друго")

- нечије НЕСТАЛности, неухватљивости:

sillet si kali në lëmë (= „врти се као коњ на вршењу“)

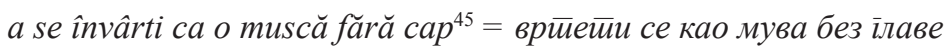

a fi / a ajunge cal de poșta / tramvai (= „бити поштански / трамвајски коњ“)

*јуриии ииамо-вамо / ићи іоре-gоле / иматии (коїа) свуgа

45 Упоредиво са разговорним: a se învârti ca un coi în caldare (= „вртети се као мудо на топлоти“). 
ФРАЗЕОЛОГИЗМИ СА ЛЕКСЕМОМ КОґ У САВРЕМЕНОМ ...

- НЕСТАБИЛНОГ КАРАКТЕРА, оДНОСНо оДСУства вЛастИТоГ ја:

мења као Циганин коње

*a schimba calimera (= „мењати добар дан“)

- НЕУСПЕХА, односно неадекватног извршавања посла:

nuk i ecën kali në vijë (= „не иде му коњ на линију“)

*не ияе му йосао како ииреба

Семантички однос можда не толико према својини колико пре према роби, односно материјалном добру, изражавају наредне делимично подударне ФК у сва три разматрана језика:

сваки Цига свога коња хвали

tot țiganul își laudă ciocanul (= „сваки Цига хвалиса се чекићем“)

çdo tregtar lavdëron mallin e vet (= „сваки трговац хвали своју робу“)

Према нашем виђењу, довођење у везу коња и Циганина у српском и румунском заснива се на укорењеном народном стереотипу о Ромима као о пословично превртљивим људима који не бирају начин да извуку корист и зараду од робе (сумњивог) квалитета и порекла коју нуде ${ }^{46}$. Потпуно иста семантичка слика се запажа и у албанском у чијем еквиваленту се у жижи налази трговац који је такође и друштвено и морално негативно окарактерисан, као особа која слаткоречивошћу придобија купце за своју робу (тј. вуну).

Наредни концепти припадају семантичким пољима која указују на:

- ОДСУСТВО ЉУДСКЕ САВРШЕНОСТИ:

kali i mirë / i kuq e ka një huq

и коњ о с сиовиину яукайа йосрне

calul are patru picioare și tot se poticnesțe

46 Како је указала Катарина Ајваган, фразеологизам је у српском настао на основу народне приче о Циганину који је на крају поверовао у све оно што је говорио о своме коњу да је одустао од његове продаје (Ајваган, 2017: 61). Свакако, не би требало заборавити ни чувену дечију песму чике Јове Змаја под сличним насловом (Циїанин хвали своїа коњ а) која је са своје стране и великог утицаја могла послужити као добра основа за ширење и додатно учвршћење овог фразеологизма у српском. 
Предраг J. Мутавџић, Мерима Кријези, Ана Б. Сивачки

- послушност, беспоговорност, сервилност:

вежи коња где ти газда / ага каже

leagă calul unde zice stăpânul, măcar lupul să-l mănâce

lidhe kalin ku të thotë "gazda" / zotëria / padroni

jam kalë karroce (=,бити коњ [за] кола“)

*бииии иоослушник

- ПРЕНАГљЕНОСТ, исхитреност, доношење одлуке на пречац:

i hipi kalit nga bishti

бржи самар оg коња / брже сеgло оg коња

a pune căpăstrul la coada calului / carul înaintea biolor

del si mëzi para pelës

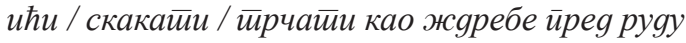

a umbla ca mânzul după iapă

ПРЕТЕРИВАњЕ, ПреувеЛичавање:

a face din cal măgar și din țânțar armăsar

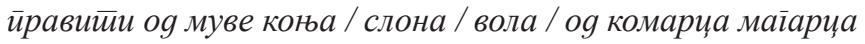

e bën mizën / pleshtin buall / ka

u rrëzua kali, t’ i presin këmbët

* неће ваљgа йаgайи йлаве збоі (чеїа) = *nи е de a-i zbura capul (cuiva) de (cineva / ceva)

Исказивање семантичког смисла просуЂИВАњА путем личне процене и вредновања некога (позитивно и/или негативно) исказују наредни албански и румунски ФРЗ (без одговарајућег фразеолошког еквивалента са зоонимом у српском):

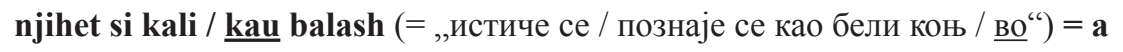
cunoaște

(pe cineva) ca un cal breaz (= „знати /кога/ као белога коња“)

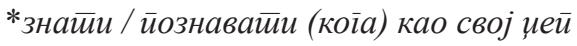

Бели коњ се у бројним народним веровањима обично везује за елеганцију, грациозност, суптилност и за позитивне одлике, насупрот 
црног коња за кога се обично сматрало да је оличење (или слуга, весник) ђавола и нечастивих сила. У народним бајкама и причама, као и у народној јуначкој епици, белог коња може јахати само изузетан и неустрашив витез, јунак пун добрих врлина, док је на црном коњу његов љути противник са којим се, по правилу, увек сукобљава.

Изражавање семантичког поља пРосторА, просторног односа, било да је реч о непосредној близини, било о некој неодређеној (замишљеној) удаљености, исказују наредни подударни румунски и албански примери:

(este) o fugă / alergătură de cal = (është) një vrap pele $(=, /$ то је/ један скок коња / кобиле“")

(налазити се se / бити) у gва скока

vajтe ku shkon këmba e kalit

a trimite pe (cineva) unde a dus (surdul roata si) mutu'iapa

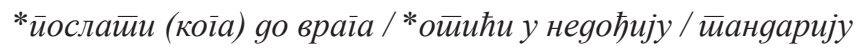

Наредни негативни концепти указују на:

- РАСИПНИШТВО:

për një gozhdë shkoi potkoi

због клинца избугио коња / *клайи вола збої киле меса

- САМовољу:

shin si kali në lëmë (= „, као коњ на вршидби“)

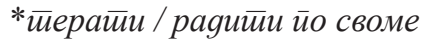

*a sti una și bună (= „знати једно и добро”)

i ka hipur kalit lakuriq (= „попео се го на коња“)

*уйастии (коме) кашика у меg / gобийи незаслужено (раяно) месиио / йозищију

- смРт: ово је једино поље у коме се уместо лексеме коњ појављује семантичка замена за њу у виду лексеме йоиковица; овде је реч о парасинонимском односу и о живој искуственој слици (коњ кад угине „окреће“/,показује“/ према небу своја копита и потковице): 
Предраг J. Мутавџић, Мерима Кријези, Ана Б. Сивачки

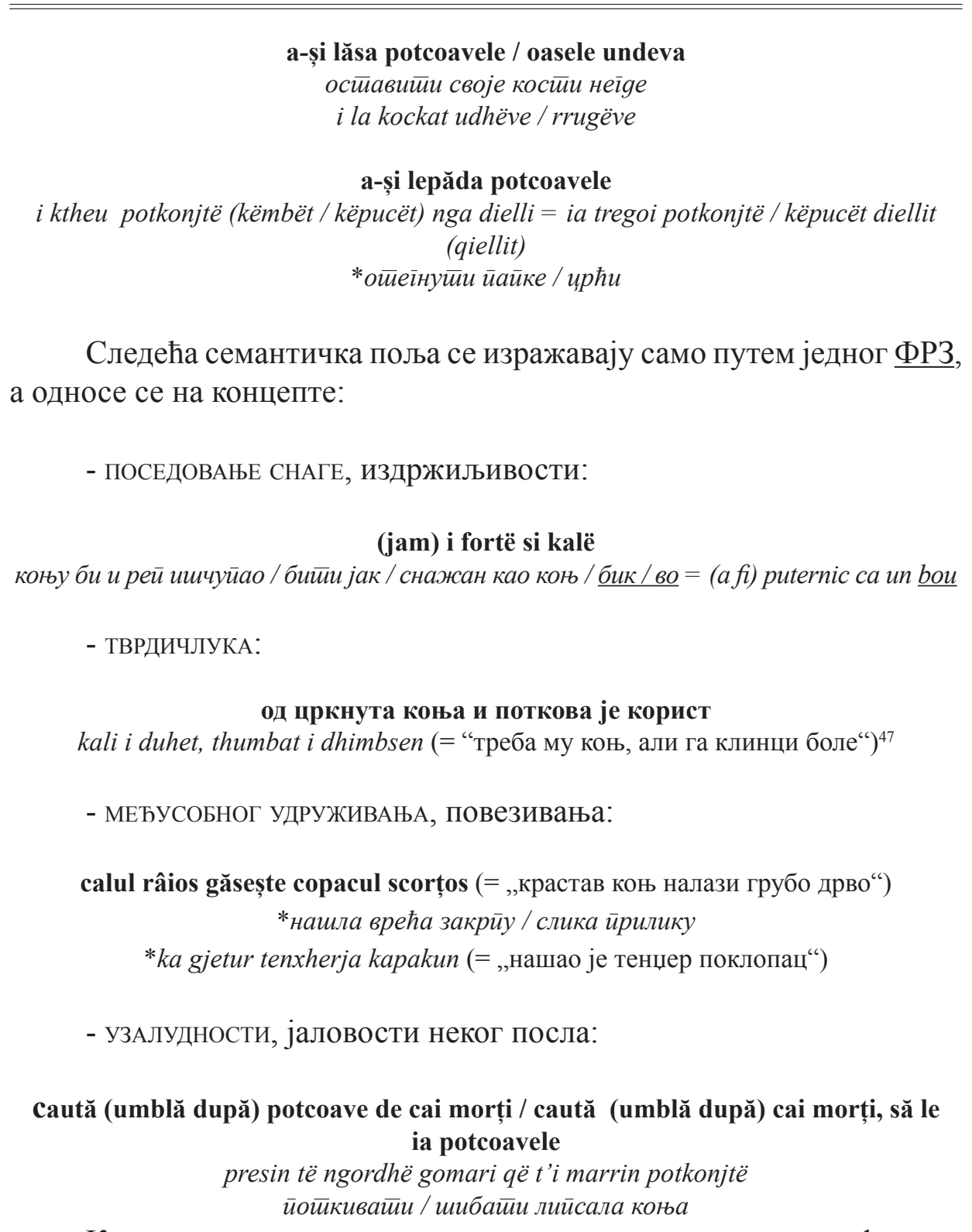

Концепт умишљЕности, покондирености носе наредни фразеологизми:

47 Смисао наведеног фразеологизма је да укаже да је неко изузетно шкрт, „бити (прави) кир-Јања“". 
ФРАЗЕОЛОГИЗМИ СА ЛЕКСЕМОМ КОґ У САВРЕМЕНОМ ...

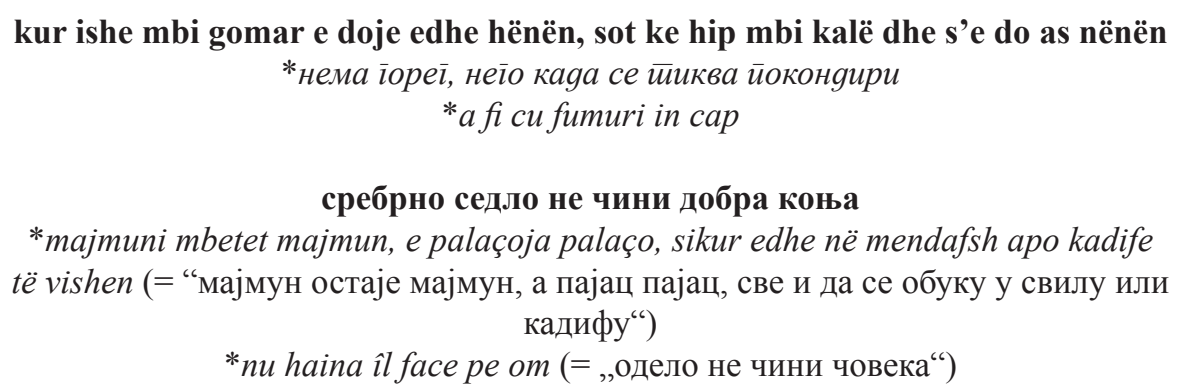

У оквиру српске фразеолошке конструкције - и ми коња за трку имамо - лексема коњ послужила је као посебан вид исказивања семантичког упореъЕњА, односно равнања, надметања и одмеравања, која се на румунски и албански може пренети једино путем нулте структурно-семантичке еквиваленције: *o să ți-o plătesc eu (cu aceeși

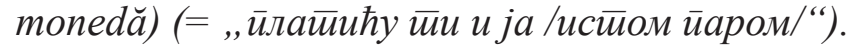

Преостала два семантичка поља се тичу концепта успешности, односно постигнутог личног домета:

\section{ka hipur mbi kalë / jam në majë të kalit}

бити на коњу / врху

a fi în vârf

те нечије извесне устАљЕности, рутине, и то у виду стечене навике која се тешко исправља:

s'mëson kali revan në pleqëri

calul bătrân cu gres se învată la ham / calul bătrân nu se mai învtaă în buiestru

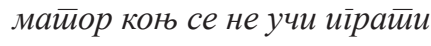

\section{7. Закључак}

Посматрајући структурну и семантичку страну фразеолошких конструкција с лексемом коњ у албанском, румунском и српском, њих деветнаест припада групи такозваних интернационалних фразеологизама, односно оних који се и у другим европским језицима препознају као такви. Од тог броја седам ФРЗ из разматраних балканских језика апсолутно је подударно са ФРЗ из других европских језика, па се зато може рећи да између њих постоји хомотипична повезаност. 
Приликом упоређења ове групе фразеологизама, запазили смо да су присутне варијанте у виду незнатних структурних, првенствено лексичких, померања, док се јасно препознаје очувана (иста) семантичка порука. Оваквих ФК са делимичним стуктурним изменама далеко је више у односу на оне код којих се исказују потпуна структурна поклапања (укупно 12). У односу на интернационалне ФК, број истих (идентичних) у албанском, румунском и српском је 5 између сва три поменута језика, 12 између румунског и српског, само 3 између албанског и румунског и 9 је истих између српског и албанског.

На основу примера наведених у раду увиђа се да превагу односи нулти апсолутни степен стуктурно-семантичке подударности између разматраних балканских језика и то 87,92\% од свих забележених примера - без обзира на то да ли су фразеолошке конструкције у полазном језику изведене од примарне или од неке секундарне зоонимске лексеме. Сагледано семантички, сви забележени ФРЗ са саставницом кољ указују на 33 различита когнитивна поља која су и позитивна и негативна - првих је далеко мање у односу на друге - а таква су поља посебне квалитативне вредности (умешност, способност), вере у самог себе, вређања, омаловажавања, губитка позиције или друштвеног положаја, временског тренутка, равнодушности итд.

Анализирајући забележен корпус ФК са лексемом коњ у албанском и румунском, запазили смо свега неколико њих које су, по своме карактеру, изразито идиотипичне за ове језике, а што их сврстава у групу подударних балканских микрофразеолошких слика.

\section{Литература}

\section{Извори}

А) једнојезични речници:

Buci, Mevlud. (2008). Fjalor me shprehje e njësi frazeologjike nga Dibra, Tiranë: Fan Noli.

Fjalor $i$ gjuhës së sotme letrare shqipe I-II. (1981). Biblioteka Linguistikë, Prishtinë: Rilindja.

Fjalor i gjuhës së sotme shqipe. (1980). Akademia e Shkencave e RPS të Shqiperisë. Tirana: Instituti i Gjuhësisë dhe i Letërsisë. 


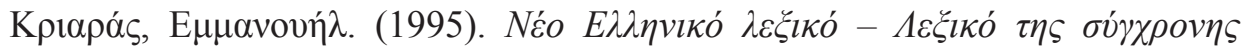

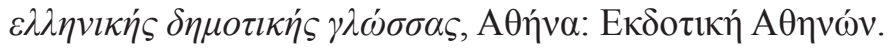

Matešić, Josip. (1982). Frazeološki rječnik hrvatskoga ili srpskoga jezika, Zagreb: Školska knjiga.

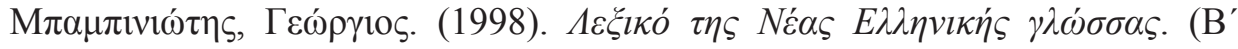

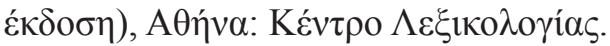

Оташевић, Ђорђе. (2012). Фразеолошки речник срйскоі језика, Нови Сад: Прометеј.

Речник срӣскохрвайскої књижевної језика. (1985). Нови Сад: Матица Српска.

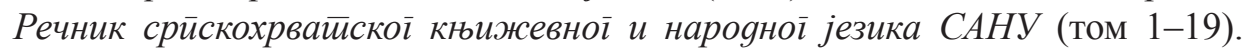
(1958 -). Београд: Институт за српски језик САНУ.

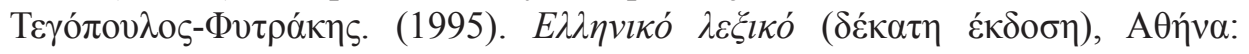

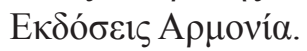

Thomai, Jani. (2010). Fjalor frazeologjik i gjuhës shqipe, Tiranë: Akademia e Shkencave e Shqiperisë -Botime EDFA.

Zeneli, Petrit. (1999). Fjalor me shprehje dhe fjalë të rralla. Tiranë: Botimet Toena.

Једнојезични речници у електронској форми

http://www.greek-language.gr/greekLang/modern_greek/tools/lexica/triantafyl$\underline{\text { lides/ }}$

http://www.dixionline.net/index.php?inputWord=gum $\% \mathrm{C} 3 \% \mathrm{~A} 3 \mathrm{r} \% \mathrm{C} 3 \% \mathrm{~A} 3 \mathrm{ts}$

https://dexonline.ro/

http://www.fjalori.shkenca.org/

Б) двојезични грчко-српски, српско-грчки, албанско-српски, српско-албански:

Albansko-srpskohrvatski rečnik(1. izdanje). (1981). Priština: Albanološki institut u Prištini.

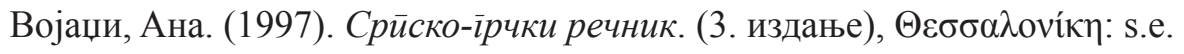

Мутавџић, Предраг. (2007). Грчко-срӣски речник ияиома. (1. издање), Београд: ИК Јасен.

Марковић, Александра. (2001). Срйско-їрчки речник. (1. издање),

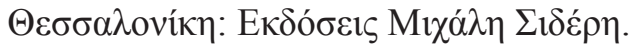

Mullafetahu, Agim. (2016). Fjalor idiomatik shqip - anglisht. Shkup - Prishtinë - Tiranë, Logos-A.

Oxford Albanian-English Dictionary (edited by Leonard Newmark). (1999). Oxford: Oxford University Press.

Srpskohrvatsko-albanski rečnik (2. izdanje). (1981). Priština: Albanološki institut u Prištini.

Стојановић, Миодраг - Балаћ, Александар. (2009). Грчко-срӣски речник (2. издање), Београд: Завод за уџбенике. 
Tomici, Mile. (2012) Dicționar frazeologic român-sârb, Timișoara: Uniunea Sârbilor din România.

В) двојезични на другим страним језицима:

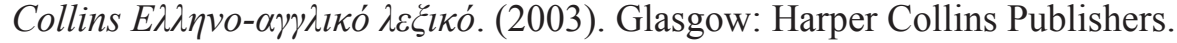

Collins Greek-English Dictionary. (1997). Glasgow: Harper Collins Publishers.

Dizionario Greco moderno-Italiano, Italiano-Greco moderno. (2006). Bologna: Perugia Edizioni.

Drimo, Ali - Bezhani, Hamlet. (1996). Deutsch-Albanisches Wörterbuch: Band 1: $A-M$. Wiesbaden: Otto Harassowitz Verlag.

Drimo, Ali - Bezhani, Hamlet. (1996). Deutsch-Albanisches Wörterbuch: Band 2: $N$-Z. Wiesbaden: Otto Harassowitz Verlag.

Fjalor rusisht-shqip. (2005). Tiranë: EDFA.

Guerini, Nicola. (2007). Fjalor i proverbave. Thënie dhe shprehje frazeologjike të traditës popullore. Tiranë: Botimet Toena.

Murati, Qemal. (2004). Fjalor i Fjalëve shqipe në maqedonishten dhe idiomatikë shqiptaro-maqedonase. Prishtinë: Logos - A.

Stavropoulos, D.N. (1995). Oxford Greek-English Learner's Dictionary. (7th edition). Oxford: Oxford Universiy Press.

Stavropoulos, D.N. - Hornby, A.S. (2011). Oxford English-Greek Learner 's Dictionary. Oxford: Oxford University Press.

Stefanllari, Illo. (2000). English-Albanian Dictionary of Idioms. New York: Hippocrene Books inc.

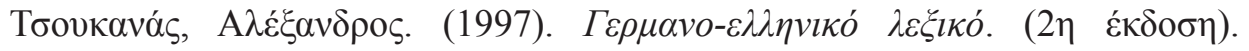

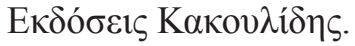

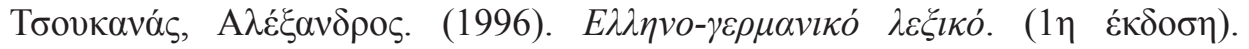

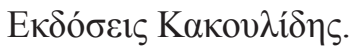

БИБЛИОГРАФИЈА

Ајваган, Катарина К. (2017). Сӣереотиии ситранщุa у језичкој слищи

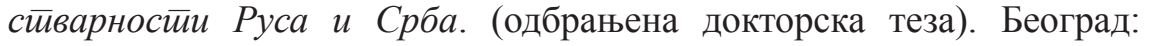
Филолошки факултет (доступно на: http://nardus.mpn.gov.rs/bitstream/ handle/123456789/9030/Disertacija.pdf?sequence=1\&isAllowed=y).

Bloomfield, Leonard. (1933). Language. Chicago: University Chicago Press.

Бојовић, Злата. (2005). „Паремије у књижевном делу“, у: Србисииччки ирилози - Зборник у части ирофесора Славка Вукомановића (Уређивачки одбор: Божо Ћорић, Љубомир Поповић, Бранкица Чигоја, Александар Милановић). Београд: Филолошки факултет, 51-57.

Conway, Deana D. J. (2005). Elemental Magick: Meditations, Exercises, Spells, and Rituals to Help You Connect with Nature. Franklin Lakes: Career Press. 
ФРАЗЕОЛОГИЗМИ СА ЛЕКСЕМОМ КОґ У САВРЕМЕНОМ ...

Christou, Panagiotis - Papastamatis, Katharini. (2009). Griechische Mythologie: Der Trojanische Krieg, die Odyssee und die Äneis. Firenze: Bonechi.

Eason, Cassandra. (2008). Fabulous creatures, mythical monsters, and animal power symbols: A handbook. London: Greenwod Press.

Ilijada (preveo i protumačio Tomo Maretić). (1948). Zagreb: Matica hrvatska.

Korfmann, Manfred. (1995). TROIA - Ausgrabungen 1994. Studia Troica, No. 5 (1995), 1-40.

Korfmann, Manfred. (1998). Troia, an Ancient Anatolian Palatial and Trading Centre: Archeological Evidence for the Period of Troia VI/VII. The Classical World, No. 91 (1998), 369-385.

Krappe, Alexandre H. (1952). La genèse des mythes. Paris: Bayot.

Latacz, Joachim. (2004). Troy and Homer: Towards a Solution of an Old Mystery. Oxford: Oxford University Press.

O’Konel, Mark - Eri, Rejdž. (2007). Ilustrovana enciklopedija simbola i znakova. Beograd-Zemun: JRJ.

Schmidt, Robert. (1980). „Kappadoker“, У: Reallexicon der Assyrologie und Vorderasiatischen Archäologie (Edzard, Dietz Otto, Herausgegeber). Band 5 Ǐa... - Kizzuwata. Berlin: Walter de Gruyter, 399-400.

Starke, Frank. (1995). Ausbildung und Training von Streitwagenpferden: Eine hippologisch orientierte Interpretation des Kukkuli-Textes. Wiesbaden: Harrassowitz Verlag.

Summerer, Latife. (2005). „Amisos - eine Griechische Polis im Land der Leukosyrer", Collection de l'Institut des Sciences et Techniques de l'Antiquité, Année 2005 / 979. Fait partie d'un numéro thématique: Pont-Euxin et polis: polis hellenis et polis barbaron. Actes du Xe Symposium de Vani (2326 septembre 2002): Hommage à Otar Lordkipanidzé et Pierre Lévêque, $129-165$.

Vidović Bolt, Ivana. (2011). „Životinja kao (ne)inteligentan čovjekov prijatelj“. Y: Ivana Vidović Bolt (urednica) Životinje u frazeološkom ruhu. Zagreb, FF Press, 1-12.

\section{Сајтографија}

https://www.ancient.eu/article/999/color-in-ancient-egypt/

https://www.linguee.com/english-greek/translation/cart+before+the+horse.html http://gimnazija-sb.com/portal/wp-content/uploads/2015/02/ezop basne.pdf 
Predrag Mutavdžić

Merima Krijezi

Ana Sivački

\section{Summary \\ IDIOMATIC EXPRESSIONS CONTAINING THE LEXEME horse IN THE MODERN ALBANIAN, ROMANIAN AND SERBIAN LANGUAGES}

This paper tackles analysis of idiomatic expressions containing the lexeme horse in three modern and genetically unrelated Balkan languages: Albanian, Romanian and Serbian. Owing to the fact that the horse is widely perceived as an immensely important animal in terms of mundane life and survival while also being extremely clean and noble, we have undertaken herein to analyze semantics of the relevant lexeme contained in idioms. It is our main aim to demonstrate how the figure of horse is used to create idioms, as well as to explore the formal morphological-syntactic and semantic aspect of the pertinent lexeme. In addition, we have also tried to draw attention to whether and to which extent there are concordances or discordances amongst the analyzed idioms.

The analysis performed herein pertains to the total of 120 recorded idiomatic expressions containing the lexeme horse excerpted from a number of general and phraseological monolingual, bilingual and multilingual dictionaries. In addition to idioms, analyzed herein are also proverbs owing to the fact that they belong to a specific phraseological group. The semantics of the recorded idioms containing the constituent horse points to the existence of a battery of various semantic fields both positive as well as negative. The total number thereof is 33 , whereas the majority of idioms are classified as negative.

Based on the analyzed examples, a conclusion can be drawn that there is predominantly zero structural-semantic concordance amongst the considered Balkan languages since this category accounts for $87.92 \%$ of all the recorded examples regardless of whether the phraseological expressions in the source languages contain a primary or a secondary zoonym. The remaining idioms belong to the category of international expressions broadly accepted and used in a variety of other European languages. Although there are only several distinctly idiotypic examples, these contain a rather unusual and highly poetic syntagm 'green horse', the origin of which remains unexplained. These idiomatic instances speak in favor of the existence of a group of congruent micro-phraseological images autochthonous to the Balkan languages.

Key words: idiomatic expressions, lexeme horse, Serbian, Albanian, Romanian, equivalence. 